UDC 68.3:616-007-053.1:616-053.31

DOI: 10.15587/2519-4798.2020.219945

\title{
ANALYSIS OF RISK FACTORS OF PERINATAL PATHOLOGY IN NEWBORNS WITH CONGENITAL DEFECTS
}

\section{A. Vlasov}

Newborns with congenital defects usually have a burdened perinatal history, and their mothers' pregnancy proceeds against the background of severe complications and exacerbation of chronic pathology. In modern obstetrics, many indicative scales are used to determine the degree of risk of perinatal and maternal pathology, including a point assessment on the Coopland scale.

The aim. Conduct a clinical and epidemiological analysis of perinatal and maternal risk factors according to the A. Coopland scale and analyze the frequency of perinatal pathology in newborns with congenital defects in the early neonatal period.

Materials and methods. We retrospectively and selectively analyzed 88 birth histories of mothers of newborns with congenital malformations who received surgical treatment in the neonatal center and scored risk factors for perinatal and maternal pathology according to the A. Coopland scale.

Results. It was revealed that mothers of newborns with congenital defects were included in the groups of high (3-6 points) and very high (7 or more) predicted risk of perinatal and maternal pathology. The high-risk group included $28(32 \%)$ mothers, and 60 women (68\%) - the very high-risk group of perinatal and maternal pathology.

Conclusions. In women with more than 15 points on the A. Coopland scale 4.7 times more often children were born with intrauterine infection, gastrointestinal disorders, NEC and severe respiratory disorders in the early neonatal period compared with mothers who gave birth to newborns with the same gestational age and a group of low and high risk of perinatal and maternal pathology

Keywords: newborns, congenital defects, risk factors, A. Coopland scale

Copyright (C) 2020, A. Vlasov.

This is an open access article under the CC BY license (http://creativecommons.org/licenses/by/4.0).

\section{Introduction}

In recent years, there have been significant changes in the care of new-borns with surgical pathology both in clinical and organizational approaches. The complexity of the diagnostic process of congenital pathology at the pre- and postnatal stage, the need to adequately address the issue of childbirth, the severity of the sick new born (combination of surgical pathology, congenital diseases, signs of morpho-functional immaturity), the need for complex surgical interventions with adequate anesthesiology rehabilitation period requires that medical care be provided to these children at level III with the provision of a multidisciplinary team of specialists (neonatal surgery center) $[1,2]$.

An example of such an approach can be the work of the neonatal departments of the Municipal Enterprise "Dnipropetrovsk Specialized Clinical Medical Center of Mother and Child named after prof. M.F. Rudneva "DRC" (neonatal surgery department, maternity ward, neonatal intensive care unit, neonatal pathology department and premature infant care), where surgical correction of the entire spectrum of neonatal malformations during the last 5 years were done - from 2015 to 2019 . According to international standards, in cases of prenatal diagnosis of developmental defects, regardless of the place of residence of the parents, delivery is performed in the maternity hospital of the center named after prof. M.F. Rudneva. In the case when the congenital malformation was not diagnosed prenatally, the infants are transferred to the center named after prof. M. F. Rudneva from maternity hospitals and medical institutions of the city and districts of the region.

In 2019 in the neonatal center Municipal Enterprise "Dnipropetrovsk Specialized Clinical Medical Center of Mother and Child named after prof. M.F. Rudneva "DRC" (ME "DSCMCMC named after Prof. M.F. Rudneva "DRC") was treated 190 children with congenital malformations and neonatal diseases who required dynamic monitoring by a surgeon (against 203 infants in 2015). Of these, 88 children $(46.3 \%)$ were operated on in 2019 , and 81 children $(40 \%)$ were operated on in 2015. Therefore, despite the decrease in the absolute number of children with birth defects, the number of cases of defects that require urgent surgical correction has increased [3].

All new-borns with congenital malformations had a burdensome perinatal history, and maternal pregnancy took place against the background of severe complications and exacerbation of chronic pathology. It is known that the level of perinatal morbidity and mortality is increased in a certain group of pregnant women and women in labor, combined in the group of "high risk" perinatal pathology. According to the literature, this group of women accounts for no more than $30 \%$ of all pregnant women, but it determines about $2 / 3$ of all perinatal losses [4]. In obstetrics, many indicative scales are used to determine the degree of risk of perinatal pathology [4, 5]. In Ukraine, a score assessment of risk factors for perinatal and maternal pathology on the scale of A. Coopland $[6,7]$. 
The aim. To conduct a clinical and epidemiological analysis of maternal risk factors on the A. Coopland scale and to analyze the frequency of perinatal pathology in new-borns with congenital malformations in the early neonatal period.

\section{Materials and methods}

Retrospectively, in 2019, 88 birth histories of mothers (F No. $096 /$ o) of new-borns with congenital malformations who received surgical treatment at the neonatal center ME "DSCMCMC named after Prof. M. F. Rudneva" "DRC" were analyzed, and a score assessment of risk factors for perinatal and maternal pathology on the A. Coopland scale [6, 7].

According to the type of birth defects in the study involved children with the pathology described in Table 1. Draws attention to the fact that most often new-borns are diagnosed with lung defects, intestinal obstruction and anorectal abnormalities. At that time, embryonic hernias and gastroschisis were less common.

Table 1

Types of birth defects in the examined children, abs. n., \%

\begin{tabular}{|c|c|c|c|c|c|c|c|}
\hline $\begin{array}{c}\text { Types of } \\
\text { birth } \\
\text { defects }\end{array}$ & $\begin{array}{c}\text { Esophageal } \\
\text { issue }\end{array}$ & $\begin{array}{c}\text { Intestinal } \\
\text { obstruction }\end{array}$ & $\begin{array}{c}\text { Embryonic } \\
\text { hernia }\end{array}$ & $\begin{array}{c}\text { Gas- } \\
\text { troschisis }\end{array}$ & $\begin{array}{c}\text { Ano-rectal } \\
\text { defects }\end{array}$ & Lung defects & Total \\
\hline $\begin{array}{c}\text { Children } \\
\text { number }\end{array}$ & $14(16 \pm 0.12)$ & $20(22 \pm 0.73)$ & $7(8 \pm 0.95)$ & $9(10 \pm 0.23)$ & $17(19 \pm 0.31)$ & $21(23 \pm 0.83)$ & $88(100)$ \\
\hline
\end{tabular}

The retrospective analysis excluded medical histories of children with urgent surgical pathology: bleeding, rupture of parenchymal organs, etc. and, if the duration of preoperative preparation, could not receive a full examination in the preoperative period, as well as infants in agonal condition.

The division of newborns and infants into groups began after admission to ME "DSCMCMC named after Prof. M. F. Rudneva" "DRC" on planned or emergency surgical treatment of congenital malformations of the surgical profile.

The method of linear discriminant function chosen for analysis according to the Coopland scale is used to classify pregnant women into three groups, namely severe, high and low risk of pregnancy. This classification depends on the risk indicators that each pregnant woman can go through during pregnancy. It is shown that the classification after the rejection of insignificant risk factors in the three groups is better than one [7].

The obtained results were processed statistically. The research results were processed on a PC, IBM PC "Microsoft Excel" and "Statistica, v. 6". The following indicators were evaluated: arithmetic mean (M), quadratic deviation $(\sigma)$, arithmetic mean error or rms error $(m)$, significant discrepancy $(\mathrm{t})$. On the basis of value of $\mathrm{t}$ and number of supervision by means of the Student's table defined reliability of differences $(\mathrm{P})$. Differences were considered significant starting from the value of $\mathrm{p}<0.05$, i.e. when the correctness of the conclusion about the presence of differences among the values could be confirmed in more than $95 \%$ of cases.

\section{Research results}

The analysis revealed that the mothers of all newborns with birth defects were in the groups of high (3-6 points) and very high (7 or more) predicted risk of perinatal and maternal pathology. The distribution of women by risk groups is presented in Table 2.

The high-risk group included $28(31 \pm 0.82 \%)$ mothers, and 60 women $(68 \pm 0.18 \%)$ - in the group of very high risk of perinatal and maternal pathology.

The highest number of points in both groups fell on the burdened obstetric history: $4.3 \pm 0.5$ and $8.6 \pm$ \pm 0.7 points, respectively, in groups I and II ( $\mathrm{p}<0.001)$.

Table 2

Distribution of mothers of newborns with congenital malformations according to the degree of risk of perinatal pathology, scores, $\mathrm{n}=88$

\begin{tabular}{|l|c|c|c|}
\hline \multirow{2}{*}{$\begin{array}{c}\text { Risk factors for perinatal and } \\
\text { maternal pathology }\end{array}$} & $\begin{array}{c}\text { High risk } \\
\text { (3-6 points) } \mathrm{n}=28\end{array}$ & $\begin{array}{c}\text { Very high risk } \\
\text { (7 or more points) } \mathrm{n}=60\end{array}$ & $\mathrm{p}$ \\
\hline Obstetric history & $4.3 \pm 0.5$ & $8.6 \pm 0.7$ & $<0.001$ \\
\hline Extragenital diseases & $2.8 \pm 1.8$ & $5.2 \pm 1.2$ & $>0.05$ \\
\hline Pregnancy & $3.7 \pm 1.4$ & $7.8 \pm 0.9$ & $<0.05$ \\
\hline
\end{tabular}

Risk factors were dominated by fetal weight less than $2500 \mathrm{~g}$ (14 women $(50 \pm 0.1 \%)$ in the high risk group and $60(100 \%)$ in the very high risk group), late preeclampsia and hypertension (4 pregnant women $(14 \pm 0.28 \%)$ in the high-risk group against $32(53 \pm 0.33 \%)$ from group of very high risk, $\mathrm{p}<0.001)$, pathological childbirth $(22(78 \pm 0.57 \%)$ and $60(100 \%)$ in the groups of high and very high risk, respectively, $\mathrm{p}<0.001)$. Significant differences were observed in women in the high and very high risk groups for perinatal and maternal pathology and during actual pregnancy: $3.7 \pm 1.4$ and $7.8 \pm 0.9$, respectively $(\mathrm{p}<0.05)$.

The most common aggravating factors during pregnancy were: premature rupture of membranes (in 2 $(7 \pm 0.14 \%)$ women in the high risk group and 36 $(60 \pm 0.11 \%)$ in the very high risk group, $\mathrm{p}<0.001)$, intrauterine fetal growth retardation $(3(11 \pm 0.71 \%)$ and 27 $(45 \pm 0.11 \%)$, respectively, in the groups of high and very 
high risk, $\mathrm{p}<0.001)$, polyhydramnios (1 $(3 \pm 0.57 \%))$ pregnant and in $13(21 \pm 0.67 \%)$ women in the high and very high risk groups, respectively, $\mathrm{p}<0.001)$, bleeding for more than 20 weeks (in $17(28 \pm 0.33 \%)$ women in the high risk group), anemia (14 (50 $\pm 0.11 \%)$ pregnant women in the high-risk group and $59(98 \pm 0.33 \%)$ in the very high-risk group, $\mathrm{p}<0.001$ ).

There were no significant differences in the frequency of extragenital pathology in women in the groups of high and very high risk ( $p>0.05$ ). Among the risk factors include the presence in women of chronic somatic diseases of the kidneys, gastrointestinal tract, respiratory system.

All pregnant women gave birth to children with varying degrees of asphyxia and perinatal pathology. Of the 28 pregnant women at high risk for perinatal and maternal pathology, $16(57 \pm 0.14 \%)$ new-borns with birth defects had a gestational age (GA) of more than 36 weeks without asphyxia, they were staying with the mother. In $12(42 \pm 0.86 \%)$ women in this group with a burdensome obstetric and infectious history, children were born in a state of moderate and severe asphyxia. Moreover, 9 (32 $\pm 0.14 \%)$ new-borns with birth defects were with GA $32-34$ weeks, $3(10 \pm 0.71 \%)$ - with gestational age $35-36$ weeks ( $\mathrm{p}<0.01$ ).

In 19 new-borns of the high-risk group due to perinatal and maternal pathology from birth there were respiratory disorders of I and II degrees of severity, 8 of which required CPAP therapy, others received moist oxygen through nasal cannulas or face mask for 3-5 days after birth.

In 9 new-borns with congenital malformations at risk of intrauterine infection during the first 4 days of life were diagnosed with perinatal bacterial infection, initiated pathogenetic and symptomatic therapy. In 7 newborns with congenital malformations (GA 32-34 weeks) from 3-4 days of life there were violations of tolerance to feeding (vomiting, lethargy, poor weight gain, stagnation in the stomach, sometimes with a mixture of bile, bloating). In the presence of changes in the clinical analysis of blood (anemia, leukocytosis), increasing intoxication syndrome, metabolic disorders, intestinal paresis, cardio-respiratory disorders, necrotizing enterocolitis (NEC) was diagnosed (in 2 new-borns).

Women in the very high risk group for perinatal and maternal pathology were divided into two subgroups depending on the total number of points: subgroup A 7-14 points and subgroup B - more than 15 points. Subgroup A included $42(70 \%)$ women, and their children with birth defects were born in a state of moderate asphyxia. In $18(30 \%)$ pregnant women of subgroup B, children with birth defects suffered severe asphyxia at birth. All children in the delivery room underwent primary resuscitation depending on the degree of asphyxia at birth: from tactile stimulation and ventilation with a bag and mask to incubation, indirect heart massage, medical correction of hypovolemia. New-borns from mothers of both subgroups were in the neonatal intensive care unit from birth, received respiratory (CPAP, mechanical ventilation), pathogenetic and symptomatic therapy.

Of the 42 neonates with birth defects from mothers of subgroup A who scored from 7 to 14 risk points who experienced moderate asphyxia at birth, 20 (47 $\pm 0.62 \%)$ newborns were with GA 28-31 weeks, $15(35 \pm 0.71-\%)$ with GA $32-34$ weeks and $7(16 \pm 0.66 \%)$ - with GA less than 28 weeks. In 18 children $(42 \pm 0.86 \%)$ intrauterine bacterial infection was diagnosed from the first day of life, in $14(33 \pm 0.33 \%)$ the syndrome of respiratory disorders of I and II degrees prevailed in the clinic and in 10 $(23 \pm 0.81 \%)$ - diagnosed with NEC during the early neonatal period.

In 18 neonates with congenital malformations from mothers who scored more than 15 subgroup B risk scores who suffered severe asphyxia at birth, the following pathology was diagnosed in the early neonatal period depending on GA. The largest number of children -10 $(55 \pm 0.56 \%)$ were born with a gestational age of 28 32 weeks, 6 new-borns $(32 \pm 0.33 \%)$ - with GA 33 36 weeks and 2 children $(11 \pm 0.11 \%)$ - with a gestational age of less than 28 weeks. In 6 new-borns with congenital malformations within 3-4 days of life were diagnosed with intrauterine bacterial infection, which in 4 infants ran with the syndrome of multiple organ failure; 8 premature infants with congenital malformations from the first hours after birth had respiratory distress of newborns, 5 children with respiratory distress syndrome during the first 4 hours of life were administered a surfactant. NEC was diagnosed with 3 neonates with systemic inflammatory response syndrome from the first 3 days of life.

Subsequently, after stabilization of the condition and intensive therapy of acute somatic comorbidities, children underwent surgical treatment for congenital malformations.

\section{Discussion of research results}

With the development of medical technology in the world, infant mortality has decreased, and infant mortality and morbidity have increased over the past half century. Moreover, the definition of high-risk pregnancies is still not generally accepted. Thus, research in the field of perinatal complications is justified. There have been studies that have suggested that short-term and long-term deficits are considered secondary to perinatal complications. Doctors often collect information about a particular child's perinatal history, but do not always aim to interpret how these complications may affect the child later. Maternal perinatal scale (A. Coopland) has shown high reliability and reliability in previous studies, but the scoring system has not yet been established [7-10]. The presented scale separates the factors that complicate pregnancy and childbirth, determines the degree of risk for the child during and after birth, which will allow neonatologists, pediatric anesthesiologists to predict the clinical situation and timely appoint a diagnostic algorithm and specify treatment and prevention measures.

Study limitations. The presented method according to the Coopland scale, which was used in the study to classify pregnant women by maternal and perinatal risk factors for pregnancy and childbirth allowed to divide these factors into three groups according to severity with the ability to predict the subsequent condition of the child after birth. Because the analysis is retrospective, there are no limitations to the study.

Prospects for further research. The identified factors in the future will be used to create a prognostic 
model of the early neonatal period in new-borns with congenital malformations, who are shown surgical treatment with individual selection of the type of anesthesia.

\section{Conclusions}

Women with a severe pregnancy with more than 15 points on the scale of perinatal and maternal risk A. Coopland, 4.7 times more likely to give birth to children with birth defects and the risk of intrauterine infection, gastrointestinal disorders and necrotizing enterocolitis, and severe respiration disorders in the early neonatal period, compared with mothers who gave birth to newborns with birth defects with the same gestational age and a group of low and high risk of perinatal and maternal pathology.

\section{Conflict of interests}

The authors declare that they have no conflicts of interest.

\section{References}

1. Horbatiuk, O. M. (2011). Suchasnyi stan khirurhii novonarodzhenykh v Ukraini ta perspektyvy rozvytku. Neonatolohiia, khirurhiia ta perynatalna medytsyna, 1, 17-20. Available at: http://nbuv.gov.ua/UJRN/Nkhpm_2011_1_1_5

2. Korytskyi, H. I., Horbatiuk, O. M. (2014). Suchasni realii ta perspektyvy neonatalnoi khirurhichnoi sluzhby na Ternopilshchyni. Sovremennaia pedyatryia, 3, 44-47. Available at: http://nbuv.gov.ua/UJRN/Sped_2014_3_11

3. Vlasov, O. O. (2020). Condition of problems of congenital developments and surgical diseases in the newborn in ukraine and the dnepropetrovsk region. Neonatology, Surgery and Perinatal Medicine, 10 (1 (35)), 6-13. doi: http://doi.org/10.24061/24134260.x.1.35.2020.1

4. Markevych, V. V. (2016). Osoblyvosti medyko-sotsialnoi kharakterystyky pershorodilei riznykh vikovykh hrup. Health of woman, 1 (107), 91-93.

5. Tarasyuk O. K., Storozhuk, M. S. (2014). Special characteristics of pregnancy and delivery course in women over 30. Actual Problems of Pediatrics, Obstetrics and Gynecology, 2. doi: http://doi.org/10.11603/24116-4944.2014.2.5899

6. Pro orhanizatsiiu nadannia statsionarnoi akushersko-hinekolohichnoi ta neonatalnoi dopomohy v Ukraini (2003). Nakaz MOZ Ukrainy No. 620. 29.12.03. Kyiv, 275.

7. Tawfeeq Al-kassab, M. M. (2001). Using Discriminant Function to Classify the Pregnants According to Coopland Risk Scale. Available at: https://www.researchgate.net/publication/339941657_Using_Discriminant_Function_to_Classify_the_Pregnants_According_ to_Coopland_Risk_Scale

8. Trammell, B. A. (2012). The maternal perinatal scale as a predictor of developmental risk. Indiana, 137.

9. Usman, U. I., Balogun, O. S. (2015). On the use of discriminant analysis in classification of the mode of delivery of an expectant mother. International Journal of Innovation and Scientific Research, 17 (2), 241-245. Available at: https://www.researchgate.net/publication/281294084_ON_THE_USE_OF_DISCRIMINANT_ANALYSIS_IN_CLASSIFICATION_OF_T HE_MODE_OF_DELIVERY_OF_AN_EXPECTANT_MOTHER

10. Levchenko, L. A. (2011). Analyz faktorov ryska razvytyia vnutryutrobnikh pnevmonyi u nedonoshennikh novorozhdënnikh. Ukrainskyi medychnyi almanakh, 14 (3), 99-101.

Received date 04.08.2020

Accepted date 23.09.2020

Published date 30.11.2020

Aleksey Vlasov, PhD, Director, Dnipropetrovsk Regional Children's Clinical Hospital of Dnipropetrovsk Regional Council, Kosmichna str., 13, Dnipro, Ukraine, 49000

E-mail: vlasovalexey75@gmail.com 